Dicle Tıp Dergisi / Dicle Medical Journal (2017) 44 (4) : 305-314

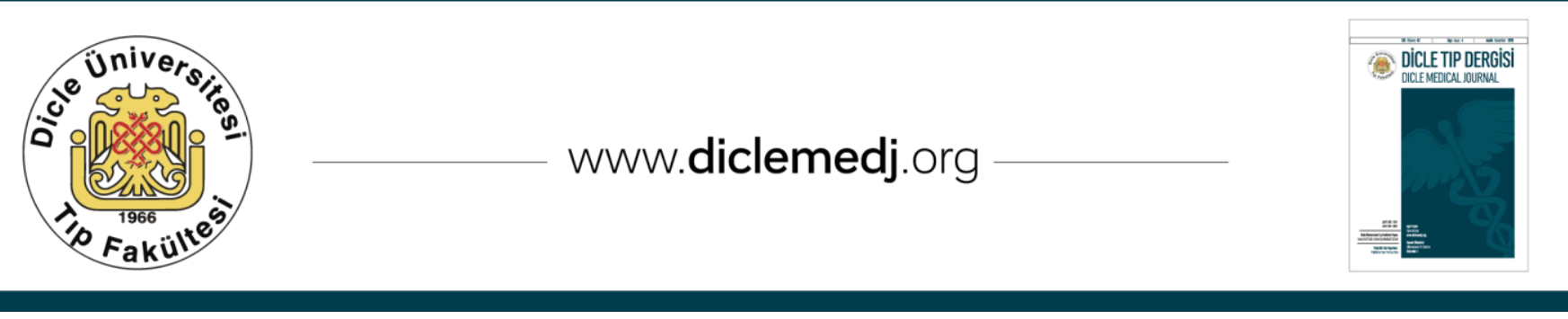

Özgün Araștırma / Original Article

\title{
Yurtta Kalan Üniversiteli Kız Öğrencilerde Metabolik Sendrom Risk Faktörlerinin Değerlendirilmesi
}

\author{
Murat Açık1 , Funda Pınar Çakıroğlu² \\ 1 Ankara Üniversitesi Sağlık Bilimleri Fakültesi, Beslenme ve Diyetetik Anabilim Dalı, Ankara, Türkiye ORCID: 0000-0002-3104-6306 \\ 2 Ankara Üniversitesi Sağllk Bilimleri Fakültesi, Beslenme ve Diyetetik Anabilim Dal, Ankara, Türkiye ORCID: 0000-0003-2324-6874 \\ Geliş: 18.08.2017, Revizyon: 11.09.1017, Kabul Tarihi: 05.10.2017
}

\section{Özet}

Amaç: Yatılı okuyan üniversiteli kız öğrencilerde metabolik sendrom (MetS) parametreleri ve buna bağlı olarak beslenme alışkanlıkları, fiziksel aktivite düzeyi ve sigara kullanma gibi faktörlerini saptamaktır.

Yöntemler: Araştırma evrenini yurtta kalan kız öğrenciler oluşturmuştur. Gönüllü onam formunu okuyup, imzalayan çalışmaya katılmayı kabul edenler arasından, istenilen bilgileri tam olan (besin tüketim sıklıkları, antropometrik ölçümleri, biyokimyasal verileri ) 90 kız öğrenci ise çalışma örneklemini oluşturmuştur. Verilerin analizi SPSS programı ile yapılmıştır.

Bulgular: Öğrencilerin sadece \%5,6'sı sigara kullandı̆̆ını bildirirken, alkol tüketenlerin oranı \% 17,8' dir. Öğrencilerin BKİ değeri $22,6 \pm 6 \mathrm{~kg} / \mathrm{m} 2$, bel çevresi $71,1 \pm 5,88 \mathrm{~cm}$, bel kalça oranı $0,72 \pm 0,04$ ve bel boy oranı $0,43 \pm 0,03$ olarak saptanmıştır. MetS risk faktörlerine bakıldığında kan biyokimyasal bulgular ve kan basıncı normal referans değer aralığındadır. Öğrencilere tüketilen öğün sayısı sorulduğunda, öğrencilerin \%63,3' ü 3 ögün tükettiği saptanmıştır. Öğrencilerin \%38,9' u düzenli olarak ana ögün yaptıklarını bildirmișlerdir. Ara öğünde bisküvi-krakerin ve çay en fazla ortalama tercih puanına sahip olduğu saptanmıștır. Öğrencilerin \%60'ı fast food, \%31,1' i gazlı içecek, \%40' 1 cips ve \%35,5' i işlenmiş et ürünlerini haftada en az bir kez tükettiklerini bildirmişlerdir. Diğger taraftan ise öğrencilerin \%26,7' si balık, \%24,4' ü yeşil yapraklı sebzeler, \%12,2' si turunçgiller, \%45,6' sı zeytinyağı ve \%43,3' ü yağlı tohumları hiç tüketmedikleri saptanmıștır. Ayrıca öğrencilerin sadece \%7,7' si günlük süt, yoğurt veya ayran tükettiği saptanmıștır. Kuru baklagil tüketimine bakıldığında, \%37,8' i on beş günde bir veya daha seyrek tükettikleri bulunmuştur. Diğer meyveleri günlük olarak tüketenlerin oranı ise sadece \%10 olduğu saptanmıştır.

Sonuç: Öğrencilerin metabolik açıdan sağlıklı profil çizgisinde olmasına rağmen beslenme alışkanlıkları konusunda yeterince iyi bir konumda değildir. Özellikle öğrencilerin çoğunluğu düzenli fiziksel aktivite yapmamaları ve ara öğünde sağlısız besinlerin öncelikli tercih etmeleri gibi bir takım olumsuz alışkanlıklar saptanmıştır. Ayrıca öğrencilerin büyük bir çoğunluğu MetS riskini azaltan bazı besin ve besin gruplarını önerilen miktarların altında aldığı tespit edilmiştir. Bu konuda ülkemizin önemli bir potansiyelini oluşturan üniversite gençlerine yönelik sağlıklı yaşam tarzının kazandırılması için yeterli ve dengeli beslenme alışkanlığı ve düzenli fiziksel aktivite alışkanlığı kazandırılması elzemdir.

Anahtar kelimeler: MetS (Metabolik Sendrom), beslenme alıșkanlıkları, üniversite öğrencileri

DOI: $10.5798 /$ dicletip.362270

Yazışma Adresi / Correspondence: Murat Açık, Ankara Üniversitesi Beslenme ve Diyetetik AD, Altındağ/Ankara, Türkiye e-mail: macik0233@gmail.com 


\title{
Assessment of Risk Factors of Metabolic Syndrome in Female University Students Residing at a Dormitory
}

\begin{abstract}
Objective: The aim is to determine metabolic syndrome (MetS) parameters in female university students who are residing at a dormitory and depending factors such as eating habits, physical activity level and smoking.

Methods: The study is consisted of female students living in the dormitory. Of the respondents who read the voluntary consent form and agreed to participate in the study, 90 female students formed whose requested information was provided (frequency of food consumption, anthropometric measurements, biochemical data) formed the sample of the study. Analysis of the data was conducted with the SPSS program.

Findings: While only $5.6 \%$ of the students reported smoking, the percentage of students consuming alcohol was $17.8 \%$. The BMI of the students was found to be $22,6 \pm 6 \mathrm{~kg} / \mathrm{m} 2$, waist circumference was $71,1 \pm 5,88 \mathrm{~cm}$, waist-hip ratio was $0,72 \pm 0,04$, and waist-height ratio was $0,43 \pm 0,03$. When the risk factors of MetS were examined, blood, biochemical findings, and blood pressure were within the normal reference values. When asked about the number of meals consumed by the students, it was found that $63.3 \%$ of the students consume their meals for three times a day. $38.9 \%$ of the students reported that they regularly consume main meals. It was determined that biscuit-cracker and tea had the highest average preference score during the snacks. It was reported that $60 \%$ of the students consume fast-food, $31.1 \%$ of them consume carbonated drinks, $40 \%$ of them consume chips and $35.5 \%$ of them consume processed meat products at least once a week. On the other hand, it was found that $26,7 \%$ of the students eat fish, $24,4 \%$ of them eat green leafy vegetables, $12,2 \%$ of them eat citrus fruits, $45,6 \%$ of them eat olive oil and $43,3 \%$ of them eat oily seeds. Moreover, it was discovered that only $7.7 \%$ of the students consume daily milk, yogurt or ayran. It was found that $37,8 \%$ of the students consume legumes once or less every 15 days. The percentage of those who consume other fruit daily is only $10 \%$.

Conclusion: Despite the fact that the students show a healthy metabolic profile, they are not in a good position on eating habits. A number of negative habits were identified, such as the fact that the majority of the students do not have regular physical activity and prefer the unhealthy food primarily during the snacks. In addition, a large majority of students were found to have received some nutrients and food groups that reduce the risk of MetS below the recommended levels. In this regard, it is essential to gain adequate and balanced eating habits and regular physical activity habits to create a healthy lifestyle for university students who constitute an important potential of our country.
\end{abstract}

Keywords: MetS (Metabolic Syndrome), eating habits, university students

\section{GíRİ̧}

Periferik sinir yaralanması sonrası iyileşmenin süresi ve kalitesi çok önemlidir. Uzun süren

Metaboliksendrom (MetS), geleneksel olarak TipII Diabetes Mellitus (TipII DM) ve kardiyovasküler hastalıkları (KVH) riskini arttıran metabolik risk faktörleri demeti olarak tanımlanır. Dünya çapında MetS prevalansına bakılacak olursa genetik, yaş, cinsiyet, etnik köken ve çevresel faktörlere bağlı olarak yaklaşık \%10 ile 84 arasında değişmektedir ${ }^{1,2}$. Klinikte MetS tanısı için kullanılan risk faktörleri glikoz intoleransı, abdominal obezite, dislipidemi, yüksek kan basıncl, protrombotik ve proinflamatuar durumun artması şeklinde sıralanabilir. Düşük dereceli bir kronik inflamasyon olan MetS' un tedavisinde multidisipliner bir yaklaşım gerekmektedir. Diyet, egzersiz, sigara kullanma durumu gibi alışkanlıklarımızda yaşam tarzının olumlu yönde değiştirilmesi gerekmektedir 3 .

MetS, dünyada en fazla ölüm nedenleri arasında sıralayabileceğimiz TipII DM ve KVH' ınmajör ayağını oluşturmaktadır. Bu yüzden yaşam tarzında yapılan değişikler ve farmakolojik ajanlar MetS' la başa çıkılma yöntemleri 
arasındadır. Ancak MetS'un klinik bulgularını bir bütün olarak kontrol altına almak zordur4. Özellikle bu konuda her bir bileşen için ayrı ayrı farmakolojik tedavi gerekmektedir. Aslında düzenli bir beslenme alışkanlığı, günlük besin alımında yeterli ve dengeli beslenme prensibi, fiziksel aktivite gibi yaşam tarzındaki modifikasyonlar MetS' la baş etme konusunda önemli birer stratejidir. Karbonhidrat veya yağ alımındaki kısıtlamalar, antioksidan alımı ya da lifli gıdaların alımındaki artış gibi bazı beslenme stratejileri MetS üzerinde terapötik etkiye sahip olabilmektedir. Fakat günümüzde ise diyeti bir bütün olarak ele alıp MetS üzerinde daha fazla terapötik etkiye sahip olacağına işaret edilmektedir. Örnek olarak sebze ve meyve, düşük yağlı süt ve süt ürünleri ve doymuş yağ asidi içeriği yüksek olan besinlerin yerine çoklu doymamış yağ asidi içeriği yüksek olan besinlerin tüketimindeki artış verilebilir. $\mathrm{Bu}$ ve buna benzer beslenme alışkanlıkları konusunda MetS' u önlemede bir takım beslenme stratejileri geliştirilmiştir. Bunlardan en önemlileri Akdeniz diyeti ve DASH diyetidir ${ }^{5}$. Güncel fiziksel aktivite rehberine göre günlük düzenli olarak en az 30 dakika orta yoğunlukta fiziksel aktivite önerilmektedir. Fiziksel aktivite ve yeterli ve dengeli beslenme insülin duyarlılığını artırmada, lipid profilini iyileștirmede ve kalp damar hastalıklarında morbidite ve mortaliteyi azaltmada etkin bir rol oynadığı saptanmıştır6.

Toplumumuzun önemli bir kesimini oluşturan üniversite öğrencileri aile ortamından ayrılmakla beraber dış etkilere daha açık bir hale gelebilmektedir. Bu etkiler öğrencilerin yaşam tarzını etkilemekle beraber fiziksel aktivite düzeyi, beslenme alışkanlıkları, sigara içme ve alkol tüketme durumlarında önemli bir dönüm noktası olabilmektedir ${ }^{7}$. Durum saptamaya yönelik bu çalışmanın amacı yatılı okuyan üniversiteli kız öğrencilerde MetS parametreleri ve buna bağlı beslenme alışkanlıkları, fiziksel aktivite düzeyi, sigara kullanma durumu gibi faktörleri saptamaktır.

\section{YÖNTEMLER}

Araștırmanın evrenini yurtta kalan üniversiteli kız öğrenciler oluşturmuştur. Çalışmaya katılan öğrencilerin kronik hastalıklarının olmaması ön koşulu aranmıştır. Gönüllü onam formunu okuyup, imzalayan çalışmaya katılmayı kabul edenler arasından, istenilen bilgileri tam olan (besin tüketim siklıkları, antropometrik ölçümleri, biyokimyasal verileri) 90 kız öğrenci ise çalışma örneklemini oluşturmuştur.

Verilerin toplanmasında öğrencilere yaş, sigara, alkol kullanımı, ailede kalp damar hastalıkları bulunma durumu, fiziksel aktivite durumu ile ilgili bilgilerin sorulduğu soru formu kullanılmıştır. Formun ikinci bölümde ise beslenme alışkanlıkları (ana ve ara öğün yapma durumları, en fazla atlanılan ana öğün ve atlama nedenleri, ara öğünde en fazla tüketilen yiyecek içecek türleri ve fastfood tüketimi) ilgili sorular sorulmuş ve besin tüketim sıklığl alınmıştır.

Beslenme alışkanlıkları bölümünde ara öğünde en çok tercih edilen yiyecek ve içecekleri tercih önceliğine göre 1,2 ve 3 olarak numaralandırmaları istenilmiştir. Ara öğünde tercih edilen yiyecek ve içeceklerin karşılaştırılmasının daha belirgin olabilmesi için $\mathrm{T}=3 \mathrm{~T} 1+2 \mathrm{~T} 2+\mathrm{T} 3$ formülünden yararlanılmıştır. Formülde birinci tercih 3 puan, ikinci tercih 2 puan ve üçüncü tercih ise 1 puan ile çarpılmış ve toplam puanlar elde edilmiştir.

Öğrencilerin son bir ayda yaptırdıkları biyokimya analiz sonuçlarından total kolesterol, HDL kolesterol, LDL kolesterol, TG, AKŞ (açlık kan şekeri düzeyi) değerleri alınmıştır. Sistolik ve diyastolik kan basınçları ölçülmüştür. Tüm sonuçlar NCEP ATP III' e göre değerlendirilmiştir. NCEP ATP III' e göre MetS komponentleri bel çevresi, AKŞ, HDL, TG, sistolik ve diyastolik kan basınçlarıdır. $\mathrm{Bu}$ kriterlerden en az üçü belirlenen sınır seviyesinin üstündeyse bireye MetS tanısı konulmaktadır. Çalışmaya bu kriterlerin yanı 
sira total kolesterol ve LDL kolesterol bulguları da dahil edilmiștir.

Verilerin analizi SPSS programı ile yapılmıştır. Nitel veriler sayı ve yüzde olarak verilmiștir. Sayısal veriler ise ortalama, standart sapma, minimum ve maksimum değerleri verilmiștir.

\section{BULGULAR}

Çalışmaya katılan $90 \mathrm{klz}$ öğrencinin yaş ortalaması 20,20 $\pm 1,25$ yıldır. Öğrencilerin sadece \%5,6' sı (5) sigara kullandığını bildirirken, alkol tüketenlerin oranı \% 17,8 (16)' dir. Öğrencilerin KVH aile öyküsüne bakıldığında; \%78,8' nin ailesinde KVH bulunmadığı, \%4,4' ünün annesinde, \%6,7' sinin babasinda, \%2,2' sinin hem anne hem de babasında, \%7,8' inin ise büyükanne veya büyükbabasında KVH bulunduğu saptanmıştır. Düzenli fiziksel aktivite yapma durumu sorgulandığında öğrencilerin \%37,8' i düzenli olarak fiziksel aktivite yaptığı ve fiziksel aktivite türünün yürüyüş veya koşu olduğu saptanmıştır (Tablo 1).

Tablo 1. Öğrencilere Ait Bazı Genel Bilgiler

\begin{tabular}{lcc}
\hline Genel Bilgiler & Sayı & $\%$ \\
\hline Sigara Kullanma Durumu & & \\
Kullanıor & 5 & 5,6 \\
Kullanmıyor & 85 & 94,4 \\
Alkol Kullanma Durumu & & \\
Kullanıyor & 2 & 2,2 \\
Kullanmıyor & 74 & 82,2 \\
Bazen Kullanıor & 14 & 15,6 \\
Düzenli Fiziksel Aktivite Yapma Durumu & & \\
Yapıyor & 7 & 7,8 \\
Yapmıyor & 34 & 37,8 \\
Bazen Yapıyor & 49 & 54,4 \\
Birinci Derecede yakınlarında KVH & & \\
olma durumu & & \\
Yok & 71 & 78,8 \\
Annede var & 4 & 4,4 \\
Babada var & 6 & 6,6 \\
Anne ve Babada var & 2 & 2,2 \\
Büyükanne ve Büyükbabada var & 7 & 8 \\
\hline
\end{tabular}

Öğrencilerin antropometrik ölçümleri incelendiğinde ortalama boy uzunluğu $163 \pm 0,05 \mathrm{~cm}$, vücut ağırlığı $60,7 \pm 5,22 \mathrm{~kg}$, BKİ $22,6 \pm 5,88 \mathrm{~kg} / \mathrm{m} 2$,kalça çevresi $98,5 \pm 5,60 \mathrm{~cm}$ olarak saptanmıştır. Ayrıca bel boy oranına bakıldığında ise ortalama değer $0,43 \pm 0,03$ iken bel kalça oranı ortalaması $0,72 \pm 0,04$ olarak bulunmuştur (Tablo 2).

MetS risk faktörlerine bakıldığında bütün değişkenler normal değer aralığındadır.

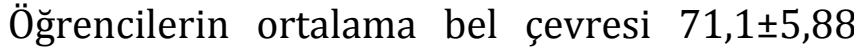
$\mathrm{cm}^{\prime}$ dir. HDL kolesterol ortalama değeri $58,1 \pm 9,26 \mathrm{mg} / \mathrm{dL}$ olup NCEP kriterlerine göre öğrencilerin \%10' u HDL kolesterol değeri düşük olduğu saptanmıştır. Serum TG düzeyi ise $86,5 \pm 31,43 \mathrm{mg} / \mathrm{dL}$ iken, öğrencilerin sadece $\% 4,4$ ' ü TG düzeyleri yüksek bulunmuştur. Öğrencilerin açlık kan şekeri ortalaması $84,4 \pm 6,77 \mathrm{mg} / \mathrm{dL}$ olduğu saptanmıştır. Sistolik ve diyastolik kan basınçları ortalamaları sirasiyla $122,3 \pm 7,19 \mathrm{mmHg}$ ve $83 \pm 6,94 \mathrm{mmHg}$ olup NCEP referans değerlerinin altındadır. Ayrıca LDL kolesterol, NCEP' e göre MetS tanı kriterleri içerisinde yer almamasına rağmen $\mathrm{KVH}$ riskinin artışında önemli rol oynar. LDL kolesterol değerinin $100 \mathrm{mg} / \mathrm{dL}^{\prime}$ nin altında olması önerilirken çalışmamızda ise $87,8 \pm 22,93$ mg/dL olduğu saptanmıştır (Tablo 3).

Çalışmaya katılan öğrencilerin beslenme alışkanları Tablo 4' te verilmiştir. Öğrencilere tüketilen öğün sayısı sorulduğunda; öğrencilerin \%63,3' ü 3 öğün, \%33,4' ü 3 öğünden fazla, \%3,3' ü ise 3 öğünden az tükettiği saptanmıştır. Öğün atlama durumlarına bakıldığında öğrencilerin \%44,4' ü bazen öğün atladığını bildirirken, \%38,9' u ise öğün atlamadığını bildirmişlerdir. Atlanılan ögünlerin $\% 42,3^{\prime}$ ü kahvaltı ögünüdür. Öğrencilerin\%56,7’ si düzenli olarak ara öğün tükettiğini bildirmişlerdir. Öğrencilerin ara ögünde tüketilen yiyeceklerin ortalama tercih puanlarına bakıldığında ilk üç sırada; bisküvikraker $(1,64 \pm 1,28)$, meyve $(1,29 \pm 1,26)$, çikolata-gofret $\quad(1,22 \pm 1,04) \quad$ olduğu görülmüştür. En çok tercih edilen ilk üç içeceğin ortalama tercih puanı ise; çay $(1,44 \pm 1,21)$, neskafe $(0,87 \pm 1,18)$ ve meyve suyu $(0,47 \pm 0,75)$ olduğu saptanmıştır. 
Tablo 2. Öğrencilere Ait Antropometrik Verileri Ortalamaları

\begin{tabular}{lccc}
\hline \multicolumn{1}{c}{ Antropometrik Veriler } & $\mathbf{X} \pm \mathbf{S S}$ & Min. & Mak. \\
\hline Boy uzunluğu (cm) & $163 \pm 0,05$ & 155 & 163 \\
Vücut ağırlığı (kg) & $60,7 \pm 5,22$ & 51 & 76 \\
BKì (kg/m²) & $22,6 \pm 1,52$ & 20,0 & 27,0 \\
Kalça çevresi (cm) & $98,5 \pm 5,60$ & 86,0 & 118,0 \\
Bel çevresi (cm) & $71,1 \pm 5,88$ & 60,0 & 87,0 \\
Bel/Kalça Oranı & $0,72 \pm 0,04$ & 0,64 & 0,85 \\
Bel/Boy Oranı & $0,43 \pm 0,03$ & 0,36 & 0,55 \\
\hline Tablo 3. MetS Risk Faktörleri Verilerinin Ortalamaları & & \\
\hline Risk Faktörleri & $\mathbf{X} \pm$ Sd & Min. & Mak. \\
\hline HDL (mg/dL) & $58,1 \pm 9,26$ & 38,0 & 89,0 \\
Trigliserid (mg/dL) & $86,5 \pm 31,43$ & 36,0 & 174,0 \\
LDL (mg/dL) & $87,8 \pm 22,93$ & 47,0 & 164,0 \\
Açlı Kan Şekeri (mg/dL) & $84,4 \pm 6,77$ & 70,0 & 105,0 \\
Sitolik Kan Basıncı (mmHg) & $122,3 \pm 7,19$ & 90,0 & 130,0 \\
Diyastolik Kan Basıncı (mmHg) & $83 \pm 6,94$ & 60,0 & 90,0 \\
\hline
\end{tabular}

MetS' la ilişkili bir takım besin gruplarının tüketim sıklığı Tablo $5^{\prime}$ te verilmiștir. Öğrencilerin sağlıksız besin veya besin grubu tüketim sıklıkları incelendiğinde, \%60' 1 fastfood, \%31,1' i gazlı içecek, \%40' 1 cips, \%35,5' i işlenmiş et ürünlerini haftada en az bir kez tükettikleri saptanmıștır. Diğer taraftan ise öğrencilerin \%26,7' si balık, \%8,9' u kuru baklagil, \%5,6' sı süt, yoğurt ve ayran, $\% 24,4$ ' ü yeşil yapraklı sebzeler, \%12,2' si turunçgiller, $\% 5,6$ ' sı diğer meyveler, \%45,6' sı zeytinyağ ve $\% 43,3^{\prime}$ ü yağlı tohumları hiç tüketmedikleri saptanmıştır. Ayrıca tereyağı tüketim sıklığı sorgulandığında; öğrencilerin \%21,1' i (19) haftada 1-2 kez tükettiğini belirtirken, \%52,3' ü (47) ise tereyağı hiç tüketmediklerini belirtmișlerdir.

\section{TARTIŞMA}

$\mathrm{Bu}$ çalışma yurtta kalan üniversitede okuyan kız öğrencilerinde MetS risk faktörlerini ve buna bağlı beslenme alışkanlıklarını değerlendirmek amacıyla yürütülmüştür. Öğrencilerin BKİ'si incelendiğinde ideal değer aralığındadır. Ashwell ve ark. $^{8}$ tarafından geliștirilmiş olan ve abdominal yağlanma konusunda fikir edinmemizi sağlayan öğrencilerin bel boy oranı incelendiğinde ise ortalamanın normal değer aralığında olduğu saptanmıştır.

NCEP' e göre MetS tanısında bel çevresi, AKŞ, TG, HDL, sistolik ve diyastolik kan basıncı yer alır. Çalışmamızda MetS riski için en önemli ayırıcı faktör olan açlık glukoz intoleransı olup öğrencilerde saptanmamıştır. Ayrıca MetS için bir diğer önemli kriter ise abdominal obezite tanısı için de kullanılan bel çevresidir. MetS tanısında bel çevresinin $88 \mathrm{~cm}$ ve üstü olması bir risk unsuru olarak belirlenmiş olup çalışmamızda ise en yüksek bel çevresi değeri $87 \mathrm{~cm}$ olarak saptanmıștır. Özellikle bu iki risk unsuru bir biriyle önemli düzeyde ilişkilidir. Öğrencilerde bu iki risk faktörün normal değer aralığında olması metabolik açıdan sağlıklı bir profil oluşmasında önemli bir katkısı bulunmaktadır9. 
Tablo 4. Öğrencilerin Beslenme Alışkanlıkları

\begin{tabular}{|c|c|c|}
\hline & Sayı & $\%$ \\
\hline \multicolumn{3}{|c|}{ Tüketilen öğün sayısı } \\
\hline 3 Öğünden Az & 3 & 3,3 \\
\hline 3 Öğün & 57 & 63,3 \\
\hline 3 Öğünden Fazla & 30 & 33,4 \\
\hline \multicolumn{3}{|c|}{ Ögüun atlama durumu } \\
\hline Atlamaz & 35 & 38,9 \\
\hline Atlar & 15 & 16,7 \\
\hline Bazen Atlar & 40 & 44,4 \\
\hline \multicolumn{3}{|l|}{ Atlanan öğün* } \\
\hline Kahvaltı & 25 & 42,3 \\
\hline Öğle öğünü & 19 & 32,2 \\
\hline Akșam öğünü & 15 & 25,5 \\
\hline \multicolumn{3}{|c|}{ Öğün Atlama Nedeni } \\
\hline Alıșkanlığım yok & 3 & 5,5 \\
\hline Vaktim yetersiz & 13 & 23,6 \\
\hline Zayıflamak için & 9 & 16,4 \\
\hline İștahsızlık & 9 & 16,4 \\
\hline Diğer nedenler & 21 & 38,1 \\
\hline \multicolumn{3}{|c|}{ Ara öğün tüketme durumu } \\
\hline Tüketir & 51 & 56,7 \\
\hline Bazen tüketir & 39 & 43,3 \\
\hline \multicolumn{3}{|c|}{$\begin{array}{l}\text { Ara Öğünde Tüketilen Yiyecek-İcceceklerin } \\
\text { Ortalama Tercih puanları }\end{array}$} \\
\hline & Ortalama & SS ( \pm$)$ \\
\hline \multicolumn{3}{|l|}{ Yiyecek Grubu } \\
\hline Bisküvi-kraker & 1,64 & 1,28 \\
\hline Meyve & 1,29 & 1,26 \\
\hline Simit-poğaça & 0,74 & 1,14 \\
\hline Çikolata-gofret & 1,22 & 1,04 \\
\hline Kuruyemiş & 0,52 & 0,85 \\
\hline Kremalı pastalar & 0,04 & 0,32 \\
\hline $\begin{array}{l}\text { Dondurma } \\
\text { İçecek Grubu }\end{array}$ & 0,08 & 0,34 \\
\hline Çay & 1,44 & 1,21 \\
\hline Neskafe & 0,87 & 1,18 \\
\hline Türk Kahvesi & 0,06 & 0,31 \\
\hline Kola & 0,31 & 0,69 \\
\hline Meyve suyu & 0,47 & 0,75 \\
\hline Ayran & 0,11 & 0,46 \\
\hline Süt & 0,22 & 0,49 \\
\hline Soda & 0,28 & 0,70 \\
\hline Bitki çayı & 0,20 & 0,31 \\
\hline
\end{tabular}

Fiziksel aktivite MetS riskini azaltmada en önemli stratejilerden biridir. Özellikle egzersizin insülin duyarlılığı üzerindeki etkisi 24. ve 48. saatleri arasında belirgin oluyor iken 3 . ve 5. günler arasında ise etkisi kaybolur ${ }^{10}$. Çalışmada öğrencilerin üçte birinden fazlası düzenli olarak fiziksel aktivite yaptığını bildirmiştir. Fiziksel aktivite yapan öğrencilerin yaklaşık \%90'ı fiziksel zindelik açısından önemli olan yürüyüş koşu gibi aerobik egzersizleri yaptıklarını belirtmişlerdir. $\mathrm{Bu}$ çalışmada, yapılmış literatürlerle karşılaştırıldığında fiziksel aktivite yapanların oranının daha yüksek olduğu saptanmıştır ${ }^{7,11}$.

Yapılan çalışmalarda, üniversite öğrencilerinde beslenme alışkanlıkları çoğunlukla düzensiz olmakla beraber öğrencilerin beslenme profilleri düşük vitamin ve yüksek yağ alımı ile karakterizedir $^{12,13}$. Kore'de üniversite öğrencileri üzerinde yapılmış çalışmada, düzensiz öğün yeme yüzdesi MetS'lu bireylerde sağlıklı kontrol grubuna göre daha yüksek çıkmıştır. Öğrencilerin \%52' si öğünlerini düzenli olarak tükettiğini belirtmiştir ${ }^{14}$. Bizim çalışmamızda ise öğrencilerin \%38,9' u öğün atlamadığını belirtmiştir. Öğrencilerin en fazla atladıkları ögün kahvaltı öğünüdür. Kahvaltı öğünü diyet kalitesi bakımından en yüksek ögündür,16 yıl takipli yapılmış bir kohort çalışmasında düzenli öğün sıklığına bağlı olarak düzenli bir şekilde kahvaltı ögünü yapanlar, yapmayan bireylere göre MetS insidansı daha düşük bulunmuştur ${ }^{15}$.

Çalışmamızda öğrencilerin yarısından fazlasının düzenli ara öğün tüketme alışkanlığının olduğu belirlenmiştir. Üniversiteli kız öğrenciler üzerinde yapılmış kesitsel çalışmada öğrencilerin \%69' u ara öğün tükettiği belirlenmiştir ${ }^{11}$. Ara öğünün tüketilme oranından daha çok, ara ögünde tüketilen yiyecekler daha önemlidir. Özellikle sağlıklı beslenme alışkanlığına sahip bir bireyler ara ögünlerde meyve, süt, sebze vb. yiyecekler tüketerek, diyet kalitesini arttırıp MetS ve birçok kronik hastalı riskini azaltabilmektedirler ${ }^{3}$. Tercihler dikkate alındığında öğrencilerin ara ögünde en fazla tükettiği yiyecekler bisküvi-kraker, meyve, çikolatalı gofret, simit-poğaça olarak sıralanmaktadır. Üniversitesi öğrencileri üzerinde yapılmış çalışmada öğrencilerin ara öğünde en çok tükettiği yiyeceklerin gözleme, cips, simit, tost, kek, çikolata-gofret olduğu belirtilmiştir ${ }^{16} . \mathrm{Bu}$ yiyeceklerin glisemik 
indeksleri yüksektir. Dolayısıyla insülin direnci veya kan TG düzeyi riskinin arttırmasıyla bir takım metabolik sorunları beraberinde getirmesi kaçınılmaz olacaktır ${ }^{17,18}$. Ara öğünde en fazla tüketilen içeceklere bakıldığında ise çay, neskafe, kola ve meyve suyu olarak sıralanmaktadır. Ayran ve süt tüketimi çok daha az tercih edilmektedir ${ }^{19,20}$.Yapılmış kohort çalışmalarında düzenli veya yüksek süt tüketiminin gerek MetS gerekse TipII DM ve KVH riskini önemli önemli derecede azalttığı saptanmıştır ${ }^{21,22}$.

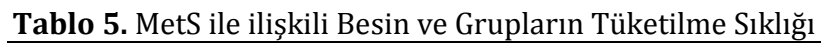

\begin{tabular}{|c|c|c|c|c|c|c|c|c|c|c|c|c|}
\hline \multicolumn{13}{|c|}{ Tüketim Sıklığı } \\
\hline \multirow{2}{*}{ Besin Grupları } & \multicolumn{2}{|c|}{ Her gün } & \multicolumn{2}{|c|}{ Gün Așırı } & \multicolumn{2}{|c|}{ Haftada 1-2 } & \multicolumn{2}{|c|}{15 Günde 1} & \multicolumn{2}{|c|}{ Ayda 1} & \multicolumn{2}{|c|}{ Tüketmiyor } \\
\hline & $\mathbf{S}$ & $\%$ & $\mathbf{S}$ & $\%$ & $\mathbf{S}$ & $\%$ & $\mathbf{S}$ & $\%$ & $\mathbf{S}$ & $\%$ & S & $\%$ \\
\hline Fastfood & 3 & 3,3 & 30 & 33,3 & 21 & 23,4 & 10 & 11,1 & 17 & 18,9 & 9 & 10,0 \\
\hline Balık & 0 & 0,0 & 2 & 2,2 & 11 & 12,2 & 7 & 7,8 & 46 & 51,1 & 24 & 26,7 \\
\hline Kurubaklagil & 12 & 13,3 & 9 & 10,0 & 35 & 38,9 & 17 & 18,9 & 9 & 10,0 & 8 & 8,9 \\
\hline Süt Yoğurt Ayran & 7 & 7,7 & 20 & 22,2 & 50 & 55,6 & 7 & 7,8 & 1 & 1,1 & 5 & 5,6 \\
\hline $\begin{array}{l}\text { Yeşil Yapraklı } \\
\text { Sebzeler }\end{array}$ & 5 & 5,6 & 6 & 6,7 & 34 & 37,8 & 10 & 11,1 & 13 & 14,4 & 22 & 24,4 \\
\hline Turunçgiller & 9 & 10,0 & 10 & 11,1 & 40 & 44,4 & 15 & 16,7 & 5 & 5,6 & 11 & 12,2 \\
\hline Diğer Meyveler & 9 & 10,0 & 14 & 15,6 & 39 & 43,3 & 22 & 24,4 & 1 & 1,1 & 5 & 5,6 \\
\hline Gazlı İçecekler & 0 & 0,0 & 4 & 4,4 & 24 & 26,7 & 10 & 11,1 & 18 & 20,0 & 34 & 37,8 \\
\hline Cips & 2 & 2,2 & 7 & 7,8 & 27 & 30,0 & 19 & 21,1 & 19 & 21,1 & 16 & 17,8 \\
\hline Tereyağı & 1 & 1,1 & 2 & 2,2 & 19 & 21,1 & 10 & 11,1 & 11 & 12,2 & 47 & 52,3 \\
\hline Zeytinyağı & 11 & 12,2 & 7 & 7,8 & 18 & 20,0 & 2 & 2,2 & 11 & 12,2 & 41 & 45,6 \\
\hline $\begin{array}{l}\text { Salam-sosis- } \\
\text { sucuk }\end{array}$ & 0 & 0,0 & 3 & 3,3 & 29 & 32,2 & 23 & 25,6 & 15 & 16,7 & 20 & 22,2 \\
\hline Yağlı Tohumlar & 3 & 3,3 & 5 & 5,6 & 11 & 12,2 & 18 & 20,0 & 14 & 15,6 & 39 & 43,3 \\
\hline
\end{tabular}

Katılımcıların metabolik açıdan sağlıklı bir profile sahip olması bireylerin yeterli ve dengeli olarak beslendiği anlamına gelmez. Genellikle beslenme alışkanlıkları konusunda çok iyi bir konumda olmayan üniversite öğrencilerin gelecekte birçok kronik hastalık riskiyle karşı karşıya kalmaktadır. Çalışmamızda MetS riskini artıran veya azaltan besin ve besin grupları tüketim sıklıkları değerlendirilmiştir. Besin tüketim sıklı̆̆ bireylerin genel olarak beslenme profili hakkında ve yeterli ve dengeli beslenmenin belirteçlerinden olan besin piramidi uyumu hakkında bilgi verir ${ }^{23}$. Yapılan bir çalışmada lise öğrencilerinin \%70'i haftada en az bir defa hamburger tükettiklerini belirtmişlerdir ${ }^{24}$.
Çalışmamıza göre kıyaslayacak olursak daha yüksek bir oran sahiptir. Balık tüketim sıklığına bakıldığında, yaklașı olarak öğrencilerin \%13' ü haftada 1-2 kez balık tükettiğini bildirmişlerdir. Güncel bir tez çalışmasında kız öğrencilerinin \%10,4'ü haftada 1-2 kez balık tükettiği bildirilmiştir ${ }^{25}$. Türkiye' ye özgü beslenme rehberine göre yeterli balık tüketim oranının oldukça düşük olduğu saptanmıştır. Balık içerisinde bulunan n-3 yağ asitleri, insülin sinyalleri ve homeostazı üzerinde olumlu etkinliğinden dolayı TipII DM ve glikoz intolerans riskini azaltmada yardımcı olabilmektedir. Ayrıca bu durum yağ asitlerin karaciğer ve kaslarda birikimini önler ve sonuç olarak metabolik olarak daha sağlıklı bir profil 
görülür. n-3 PUFA'lar inflamasyon, platelet aktivasyon, endoltelyal fonksiyon ve kan basıncı üzerinde regüle edici özelliğe sahip olduğu için MetS riskini düşürebilmektedir ${ }^{26}$.

Çalışmada süt ve süt ürünleri tüketim sıklı̆̆na bakıldığında öğrencilerin çok az bir kısmı her gün süt tükettiklerini belirtmişlerdir. Gençlerin önerilen günlük süt tüketimi 350 gr iken üniversite öğrencileri üzerinde yapılan bir çalışmada günlük süt tüketim miktarı 100 gr'dır ${ }^{27}$. Özellikle yapılan çalışmalarda gençlerde, süt tüketiminin günlük alım düzeyinin oldukça altında olduğu belirtilmiştir ${ }^{11,27}$. Süt ve süt ürünleri içerisinde yer alan orta zincirli yağ asitleri insülin duyarlılı̆̆ pastörize süt gibi probiyotik içeren ürünler yağ emilimini azaltarak daha iyi bir lipid profil oluşumunda rol alır. $\mathrm{Bu}$ durum süt ve süt ürünlerinin MetS üzerinde olumlu etkilere sahip olduğunu açıkça göstermiştir ${ }^{28}$.

Yeterli ve dengeli bir beslenme programında sebze ve meyve önemlidir. İçerisindeki MetS etiyolojisinde yatan proinflamatuvar sitokinleri etkisizleştiren antioksidanlardan zengindir. Ancak yeşil yapraklı sebze, turunçgiller ve diğer meyvelerin günlük düzenli olarak tüketim sıklığının çok düşük olduğu saptanmıştır. Türkiye' ye özgü beslenme rehberine göre kalp damar hastalıkları, TipII DM' ye karşı korunmak için günde en az 5 porsiyon sebze ve meyve tüketimi önerilmektedir ${ }^{23}$. Tahran' da yapılmış kesitsel bir çalışmada sebze ve meyveyi günlük önerilen miktar veya üzerinde alanların, altında alanlara göre MetS riski sırasiyla $\% 30$ ve 34 daha düşük saptanmıştır ${ }^{29}$.Çalışmamıza katılanların büyük bir çoğunluğunun günlük önerilen miktarın altında sebze meyve tüketiyor oluşu gelecekte MetS görülme riskinin artacağını düşündürmektedir.

Günümüzde gençler arasında gazlı içecek tüketimi büyük oranda artış göstermiştir. ABD' de yapılan bir çalışmada 1976 ile 2006 yılları arasında gazlı içecek tüketimi kişi başına yaklaşık olarak 2 kat artmıştır ${ }^{30}$. Yetişkinler ve adölesanlar da ağırlık kazanımı ve obeziteye neden olan gazlı içecekler metabolik açıdan sağlıksız bir profil riski yaratabilmektedir. Üniversite öğrencileri üzerinde yapılmış bir çalışmada, öğrencilerin yaklaşık olarak \%45' i gazlı içecek tükettiğini bildirmiş olup, çalışmamıza kıyasla daha yüksek bir bulgu elde edilmiştir ${ }^{20}$. Geniş katılımcı barındıran meta analiz derlemesinde ayda en az 1 kez gazlı içecek tüketenlerde, tüketmeyenlere göre MetS insidansında \%20 artış olduğu saptanmıştır ${ }^{31}$.

Sonuç olarak öğrencilerin tamamı metabolik açıdan sağlıklı bir profil çizgisinde olduğu saptanmıştır. Ancak gençlerin büyük bir çoğunluğu düzenli fiziksel aktivite yapmaması, en fazla atlanılan ögünün kahvaltı öğünü oluşu ve buna bağlı olarak diyet kalitesinde düşüş görülmesi, ara öğünlerde bisküvi-kraker, simit poğaça ve çikolata gibi sağlıksız besinlerin en fazla tercih edilen olması gibi nedenler gençlerde ileriki dönemlerde MetS ve buna bağlı olarak TipII DM ve KVH riskinde artışa neden olabileceğini düşündürmektedir. Gençlerde fastfood, gazlı içecekler ve işlenmiş et ürünleri tüketiminin fazla oluşu ve süt, meyve ve sebze başta olmak üzere balık tüketimi ve yağlı tohumların tüketim sıklığının az oluşu diyetin kalitesini düşürmektedir. MetS' la en etkin bir şekilde mücadelenin sürdürülmesi için yeterli ve dengeli beslenme, düzenli fiziksel aktivite yapılması ve sigara kullanmama gibi önlemler alınması şarttır. Bu konuda ülkemizin önemli bir potansiyelini oluşturan üniversite gençlerine yönelik beslenme eğitimlerinin verilmesi, yeterli ve dengeli beslenme alışkanlığı ve düzenli fiziksel aktivite alışkanlığı kazandırılması elzemdir. 
Çıkar Çatışması Beyanı: Yazarlar çıkar çatışması olmadığını bildirmişlerdir.

Finansal Destek: Bu çalışma her hangi bir fon tarafından desteklenmemiştir.

Declaration of Conflicting Interests: The authors declare that they have no conflict of interest.

Financial Disclosure: No financial support was received.

\section{KAYNAKLAR}

1. Desroches S, Lamarche B. The evolving definitions and increasing prevalence of the metabolic syndrome. Applied Physiology, Nutrition, and Metabolism 2007; 32:23-32.

2. Kolovou GD, Anagnostopoulou KK, Salpea KD, et al. The prevalence of metabolic syndrome in various populations. The American journal of the medical sciences 2007; 333:362-71.

3. Kaur J. A comprehensive review on metabolic syndrome. Cardiology research and practice 2014; 2014.

4. Reaven GM. Role of insulin resistance in human disease. Diabetes 1988; 37:1595-607.

5. Andersen CJ, Fernandez ML. Dietary strategies to reduce metabolic syndrome. Reviews in Endocrine and Metabolic Disorders2013; 14:241-54.

6. Koplan JP, Dietz WH. Caloric imbalance and public health policy. Jama 1999; 282:1579-81.

7. Arslan SA, Daşkapan A, Çakır B. Üniversite öğrencilerinin beslenme ve fiziksel aktivite alışkanlıklarının belirlenmesi. TAF Preventive Medicine Bulletin 2016; 15.

8. Ashwell M, Hsieh SD. Six reasons why the waist-toheight ratio is a rapid and effective global indicator for health risks of obesity and how its use could simplify the international public health message on obesity. International journal of food sciences and nutrition 2005; 56:303-7.

9. Eckel RH, Grundy SM, Zimmet PZ. The metabolic syndrome. The lancet 2005; 365:1415-28.

10. Haskell WL, Lee I-M, Pate RR, et al. Physical activity and public health: updated recommendation for adults from the American College of Sports Medicine and the American Heart Association. Circulation 2007; 116:1081.
11. Güleç M, Yabancı N, Göçgeldi E, et al. Ankara'da iki kız öğrenci yurdunda kalan öğrencilerin beslenme alışkanlıkları. Gülhane Tıp Dergisi 2008; 50:102-9.

12. Tzotzas $\mathrm{T}$, Konstantinidis $\mathrm{T}$, Bougoulia $\mathrm{M}$, et al. Factors associated with body mass index in adults from Northern Greece. HORMONES-ATHENS- 2004;3:111-9.

13. Serra-Majem L, García-Closas R, Ribas L, et al. Food patterns of Spanish schoolchildren and adolescents: The enKid Study. Public health nutrition 2001; 4:1433.

14. Shin A, Lim S-Y, Sung J, et al. Dietary intake, eating habits, and metabolic syndrome in Korean men. Journal of the American Dietetic Association 2009; 109:633-40.

15. Jääskeläinen A, Schwab U, Kolehmainen $M$, et al. Associations of meal frequency and breakfast with obesity and metabolic syndrome traits in adolescents of Northern Finland Birth Cohort 1986. Nutrition, Metabolism and Cardiovascular Diseases 2013; 23:1002-9.

16. Açılköz S. Üniversite öğrencilerinin beslenme alışkanlıkları ile özyetkinlik ve iyimserlik ilişsisi: Ankara üniversitesi örneği. Yayımlanmamış Yüksek Lisans Tezi, 2006 Ankara Üniversitesi, Sağlık Bilimleri Enstitüsü, Ankara.

17. McKeown NM, Meigs JB, Liu S, et al. Carbohydrate nutrition, insulin resistance, and the prevalence of the metabolic syndrome in the Framingham Offspring Cohort. Diabetes care 2004; 27:538-46.

18. Juanola-Falgarona M, Salas-Salvadó J, Buil-Cosiales $\mathrm{P}$, et al. Dietary Glycemic Index and Glycemic Load Are Positively Associated with Risk of Developing Metabolic Syndrome in Middle-Aged and Elderly Adults. Journal of the American Geriatrics Society 2015; 63:1991-2000.

19. Saygın M, Öngel K, ÇALIŞKAN S, et al. Süleyman Demirel Üniversitesi öğrencilerinin beslenme alişkanliklari. SDÜ Tıp Fakültesi Dergisi 2011;18.

20. Yllmaz E, Özkan S. Üniversite öğrencilerinin beslenme alışkanlıklarının incelenmesi. Fırat Sağlık Hizmetleri Dergisi 2007;2:87-104.

21. Elwood PC, Pickering JE, Fehily AM. Milk and dairy consumption, diabetes and the metabolic syndrome: the Caerphilly prospective study. Journal of Epidemiology \& Community Health 2007; 61:695-8.

22. Babio N, Becerra-Tomás N, Martínez-González MÁ, et al. Consumption of yogurt, low-fat milk, and other lowfat dairy products is associated with lower risk of metabolic syndrome incidence in an elderly Mediterranean population. The Journal of nutrition 2015; 145:2308-16.

23. Beslenme HÜSBF, Bölümü D. Türkiye'ye Özgü Besin ve Beslenme Rehberi. Ankara, Hacettepe Üniversitesi 2015. 
24. Türk M, Gürsoy T, Ergin I. Kentsel bölgede lise birinci sınıf öğrencilerinin beslenme alışkanlıkları. GenelTıpDerg2007 2007;17:81-87.

25. Erçim RE. Üniversite Öğrencilerinin Beslenme Durumlarının Değerlendirilmesi ve Sağlıklı Yeme Indekslerinin Saptanması. Yayımlanmamış Yüksek Lisans Tezi, 2014, Hacettepe Üniversitesi, Sağlık Bilimleri Enstitüsü, Ankara.

26. Carpentier YA, Portois L, Malaisse WJ. n- 3 Fatty acids and the metabolic syndrome. The American journal of clinical nutrition 2006; 83:S1499-1504S.

27. Tarakçı Z, Selçuk Ş, Şahin K, et al. Üniversite öğrencilerinin içme sütü tüketim alışkanlıkları üzerine bir araştırma. Yüzüncü Yıl Üniversitesi Tarım Bilimleri Dergisi 2003; 13:15-21
28. Pfeuffer M, Schrezenmeir J. Milk and the metabolic syndrome. Obesity reviews 2007; 8:109-18.

29. Esmaillzadeh A, Kimiagar M, Mehrabi $Y$, et al. Fruit and vegetable intakes, C-reactive protein, and the metabolic syndrome. The American journal of clinical nutrition 2006; 84(6):1489-1497.

30. Popkin BM. Patterns of beverage use across the lifecycle. Physiology \& behavior 2010; 100:4-9.

31. Malik VS, Popkin BM, Bray GA, et al. Sugar-sweetened beverages and risk of metabolic syndrome and type 2 diabetes. Diabetes care 2010; 33:2477-83 